

\title{
Issues in urban land and property markets in developing and transitional countries - Some experiences in Sri Lanka
}

\author{
R G Ariyawansa* \\ B. Sc. Estate Management and Valuation (University of Sri Jayewardenepura); M.Sc. Management (University of Sri Jayewardenepura); \\ M.Sc. in Development and Planning (International Housing Studies) (University of London)
}

Efficient land and property markets are responsible for different functions such as allocation and reallocation of land, providing required residence for all communities, store of wealth by providing investment opportunities, mobilizing real estate wealth and maintaining closer relationship with financial sector etc. Matured property markets in developed cities exhibit particular characteristics relating to such expected functions of property markets such as:

- Accommodation of full range of use and investment objectives

- Flexible market adjustment in both short and long term

- Existence of a sophisticated property profession and associated institutional networks

- Extensive information flows and research activity

- Market openness in special, functional and sectoral terms

- Standardisation of property rights and market price (Keugh \& D'Ary, 1994 in James \& Staney, 1999).

Sound monetary and fiscal policy, stable political environment, private property rights and favourable laws and regulations relating to property rights, freedom to repatriate earnings, flexible and unrestrictive control over the foreign exchange, favourable labour laws, good infrastructure, good location, adequate promotion such as tax concession etc, are general factors for the success of the market system, which is needed for efficient land and property markets in a country. For that, the role of the public sector is very vital and significant. Gavin et al (2000) indicate some particular functions that governments must undertake to facilitate property markets such as a) the basic property law of the country, b) make access to courts and tribunals, c)land registries, d)physical planning and building regulations, e)proper management of the operational lands and, $f$ )operation of fair tax system.

In fact, there is a strong political and social rationale for the existence of efficient real estate markets in any context. Democracy on property i.e. right to have private property and freedom to sell or buy are essential features for a property market. Sri Lanka exhibits a substantial democracy on real estate property to enjoy private ownership and the freedom to sell and buy.

Currently, most developing and former socialist countries are overwhelmingly adopting open economic policies to achieve rapid economic growth. Accordingly, developing cities hastily step forward to function as international markets that promote international property markets as well. This simply means that the overall economic development of a country, by and large, determines the performance of property markets and vice versa. However, the existing legislative and other systems in such countries presumably are not appropriate for the purpose. Proving this, James \& Staney (1999) have pointed out that the issue of foreign ownership of land and landed property is a critical determinant of the market performance in most of emerging markets in developing countries. Therefore, it seems that although countries have taken some radical economic reforms, implementation and development of such policies take unnecessarily long periods. Attitudes among some local community are dissimilar in temperament with international market perspectives too. For instance, in Sri Lanka, some argue that patriotic attitudes especially over the ownerships of land and landed property create contradictions with the market mechanism.

Market approach has been adapted in Sri Lanka since late 1970's. As a result, during the 1980's, the real estate sector became a highly popular industry, where massive amounts were invested making the real estate companies as a highly performed sector in the Colombo Stock Exchange (Central Bank of Sri Lanka, 1998). Also, there are ample evidence of market transactions of luxury and super luxury properties in Colombo similar to developed cities in the world. However, the World Bank (2000) indicates that the market mechanism is discouraged by illdefined land rights and limited capacity of land registry etc, resulting de-motivating demand and supply forces, delaying the development and transaction, disappointing the investors, increasing the risk and the total cost. Further, in Colombo, the most striking trend regarding urban land and property market is artificially created high price of land and properties. It implies that there is a lack of standardization of property and property price. In addition, inadequate and improperly managed infrastructure, especially the 
road network, transport systems, and other basic utilities severely obstruct the market performance.

The relationship between the real estate market and the financial sector is also important. In fact, there is an issue of integration of financial sector with real estate sector in developing countries. Saunders's (1990) analysis of housing markets in the UK shows that properly integrated insurance and pension funds with the housing sector has led to higher market performance. Initial policy changes in the 1970's and 1980's in Sri Lanka have also made a wide impact on the financial sector to establish many local as well as foreign financial institutions and instruments. However, the financial sector's integration with real estate development and marketing is questionable, especially since the country has many unorganized or informal activities. For instance, most of the organized property developers are also engaged in mere land subdivision and selling of land as raw materials. Individuals have to carry out the development part in unorganized and informal ways, where integration of other sectors such as financial is not easy. Hence, it seems that the market plays an incomplete role.

Therefore, it seems that although some steps have been taken to reform the economic activities at a policy level, changes in practical context are not adequate. As such, the market system is not operated as expected. Generally in any developing context, the public sector is not successful due to rigid and weak planning system while the private sector is not successful due to higher cost and insufficient services in connection with the real property markets.

In conclusion, it is clear that there are some positive features for property markets in the country along with the liberal economic policies, however, at the same time there are severe barriers, due to which the market is unable to function as an efficient property market.
Naturally scarce and complex real estates coupled with various forms of social, economic, and political variables entail inevitable inefficiency in the real estate sector in the country. State vision on efficient real estate markets has to be reshaped and reformed. Areas such as research and development, internationally accredited professional practices, integration of different sectors and scientifically managed infrastructure should be encouraged to ensure the objectives of property markets.

\section{References:}

Central Bank of Sri Lanka, (1998). Economic Progress of Independent Sri Lanka, Central Bank, Sri Lanka

Central Bank of Sri Lanka, (2000). Annual Report, Central Bank, Sri Lanka

James, B. and Staney, McG. (ed.) (1999). Cities in the Pacific Rim: Planning Systems and Property Markets, E \& FN Spon, UK

Gavin, et al (2000), "Developing real estate markets in transitional economies," A paper presented at the UN International Conference 6-8 December 2000, Geneva

Saunders, P. (1990). A Nation of Home Owners, Academic Division of Unwin Hyman Ltd, London

World Bank, (2000). "Sri Lanka recapturing missed opportunities: poverty reduction and economic management South Asian region, Report No. 20430-CE, The Would Bank, Washington, D.C

${ }^{*} R$ G Ariyawansa is a Senior Lecturer in Real Estate Management and the Head of the Dept. of Estate Management and Valuation, University of Sri Jayewardenepura. He has been trained in estate management and valuation, management and development planning in Sri Lanka and UK. 